\title{
THE EFFECT OF FOOT TYPE ON THE FOOT MORPHOLOGY AND PLANTAR PRESSURE DISTRIBUTIONS OF OBESE CHILDREN
}

\author{
Shiyang YAN ${ }^{1}$, Yue WANG ${ }^{2}$, Ruoyi $\mathrm{LI}^{1}$, Linshan ZHANG ${ }^{2}$, Wuyong CHEN ${ }^{1}$, Luming YANG ${ }^{1}$ \\ ${ }^{1}$ Key Laboratory of Leather Chemistry and Engineering (Sichuan University), Ministry of Education, Chengdu, China \\ ${ }^{2}$ National Engineering Laboratory for Clean Technology of Leather Manufacture, Chengdu, China
}

Received: 03.08.2017

Accepted: 16.11.2017

https://doi.org/10.24264/Ifj.17.4.6

THE EFFECT OF FOOT TYPE ON THE FOOT MORPHOLOGY AND PLANTAR PRESSURE DISTRIBUTIONS OF OBESE CHILDREN

ABSTRACT. Obese children with flatfoot tolerate not only the excessive load, but also the foot structure deformity. The purpose of this study is to investigate the effect of different foot types on the foot morphology and plantar pressure distributions of obese children. Relative data of 30 obese children with flatfoot and another matched 30 obese children with normal arch foot were recorded. When the foot measures were normalized to the length of the foot, significantly lower instep height and longer instep circumference were found in obese children with flatfoot. Obese children with flatfoot displayed significantly greater pressure rate and force-time integral beneath the midfoot region, while displayed decreased load pattern beneath the $5^{\text {th }}$ metatarsal region. Small variations in foot morphology must be incorporated to the last design to meet the comfort and functionality requirements of specialized shoe for obese children with flatfoot. Obese children with flatfoot could be at an increased risk for midfoot injuries such as stress fractures.

KEY WORDS: flatfoot, obese children, foot morphology, dynamic plantar pressure distribution

INFLUENȚA TIPULUI DE PICIOR ASUPRA MORFOLOGIEI PICIORULUI ȘI DISTRIBUȚIEI PRESIUNII PLANTARE LA COPIII OBEZI

REZUMAT. Copiii obezi cu picior plat tolerează nu numai sarcina excesivă, ci și deformarea structurii piciorului. Scopul acestui studiu este de a investiga influența diferitelor tipuri de picior asupra morfologiei piciorului și distribuției presiunii plantare la copiii obezi. Au fost înregistrate datele a 30 de copii obezi cu picior plat și 30 de copii obezi cu boltă plantară normală. După normalizarea măsurătorilor privind lungimea piciorului, la copiii obezi cu picior plat s-a constatat înălțimea semnificativ mai mică a căputei și circumferința mai mare a căputei. Copiii obezi cu picior plat au prezentat o rată de presiune și o integrală forță-timp semnificativ mai mari în regiunea mediană a piciorului, în timp ce sarcina a fost redusă în regiunea celui de-al 5-lea metatarsian. Micile variațiuni în morfologia piciorului trebuie să fie încorporate în designul calapodului pentru a satisface cerințele de confort și de funcționalitate ale pantofilor specializați pentru copiii obezi cu picior plat. Copiii obezi cu picior plat ar putea prezenta un risc crescut de leziuni în regiunea mediană a piciorului, cum ar fi fracturile de stres.

CUVINTE CHEIE: picior plat, copii obezi, morfologia piciorului, distribuția presiunii plantare în dinamică

L'EFFET DU TYPE DE PIED SUR LA MORPHOLOGIE DU PIED ET LA DISTRIBUTION DE LA PRESSION PLANTAIRE CHEZ LES ENFANTS OBÉSES

RÉSUMÉ. Les enfants obèses avec le pied plat tolèrent non seulement la charge excessive, mais aussi la déformation de la structure du pied. Le but de cette étude a été d`étudier lıeffet de différents types de pieds sur la morphologie du pied et la répartition de la pression plantaire chez les enfants obèses. Les données relatives à 30 enfants obèses avec le pied plat et 30 autres enfants obèses avec une voûte plantaire normale ont été enregistrées. Les mesures ont été normalisées à la longueur du pied et chez les enfants obèses avec le pied plat ont a trouvé la hauteur de la cambrure significativement inférieure et la circonférence de la cambrure plus longue. Les enfants obèses avec le pied plat ont montré un taux de pression et une force-temps significativement plus importants sous la région du milieu du pied, tandis que la charge a été réduite sous la région du $5^{\text {ème }}$ métatarse. Les petites variations dans la morphologie du pied doivent être intégrées à la conception des formes pour les chaussures pour répondre aux exigences de confort et de fonctionnalité de la chaussure spécialisée pour les enfants obèses avec le pied plat. Les enfants obèses avec le pied plat pourraient être plus à risque de subir des blessures au mi-pied comme des fractures de stress. MOTS CLÉS : pied plat, enfants obèses, morphologie du pied, répartition dynamique de la pression plantaire

\footnotetext{
* Correspondence to: Luming YANG, Key Laboratory of Leather Chemistry and Engineering (Sichuan University), Ministry of Education, Sichuan University, No.24 in South pare of First ring road, Wuhou district, Chengdu, Sichuan, China, e-mail: ylmll1982@126.com
} 


\section{INTRODUCTION}

Childhood obesity is perceived as a great possibility of becoming adult obesity. Obese children's implication in orthopaedic problems is mainly associated with excessive and repetitive load. Particularly, the association of foot structure, especially of flatfoot, and children with obesity has been widely researched [1-5]. Sadeghi-Demneh et al. [4] and Pfeiffer et al. [6] have demonstrated the significant association of body mass with flatfoot in school- and preschool-aged children. Numerous studies have acknowledged that with increasing the body mass, the proportion of children with flatfoot increased [6-9].

Therefore, flatfoot presents a high incidence in obese children. Obese children with flatfoot suffer not only greatly from the excessive body mass, but also deformity in the foot structure. It has been found that individuals with flatfoot were at a high risk for the development of lower limbs injuries, such as metatarsal stress fractures, iliotibial band syndrome, and patellofemoral pain syndrome [10]. Besides, previous literature has indicated that individuals with flatfoot could be at an increased risk for the development of medial and lateral midfoot injuries [11]. However, Chuckpaiwong et al. [12] focused on altered plantar loading patterns as it is related to foot type and reported that individuals with flatfoot were at a lower risk for lateral column metatarsal stress fractures.

Flatfoot, as a typical consequence of foot deformity for obese children, should be further investigated in the future study. However, to date, the variations in foot morphology and dynamic plantar pressure distribution of obese children with flatfoot have not been discussed in previous study. This study was designed to investigate the variations in foot morphology and plantar pressure of obese children with flatfoot relative to the obese children with normal arch foot. The purpose of this pilot study was to investigate the effect of foot types (lower arch type and normal arch type) on the foot morphology and dynamic plantar pressure distribution of obese children. Are obese children with flatfoot at a high risk for foot deformity and foot injuries?

\section{METHODS}

\section{Participants}

All the participants were selected from a foot morphology database of totally 551 children, including 280 boys and 271 girls, aged 7-16 years. All the participants were recruited from consenting primary schools and middle schools, Chengdu and Yantai, China. The arch structure was calculated simultaneously by Foot Angle (FA) and Chippaux-Smirak Index (CSI). Footprints of each subject were classified into high, normal, intermediary, lower and flat arch to characterize the surface area of each child's foot in contact with the ground, following the protocol of Forriol and Pascual [13].

Totally 30 obese children with flatfoot (OFF group) aged 7-14 years (9 girls and 21 boys) without other foot diseases and health problems were selected from this database. Another 30 obese children with normal arch foot (ONAF group) ( 9 girls and 21 boys), matched to their counterparts for age, gender and body mass index (BMI), were also collected from the same database. Obesity was defined by the body mass index (BMI) reference norm which was established by Group of China Obesity Task Force (GCOTF) [14]. BMI was calculated by the following formula: $\mathrm{BMI}=$ weight $/$ height $^{2}\left(\mathrm{~kg} / \mathrm{m}^{2}\right)$. Descriptive characteristics were shown in Table 1.

Table 1: Descriptive characteristics" of participants

\begin{tabular}{ccc}
\hline & Group 1 & Group 2 \\
\hline Age (year) & $9.1 \pm 1.9$ & $9.1 \pm 1.9$ \\
Height $(\mathrm{cm})$ & $143.8 \pm 10.8$ & $142.0 \pm 10.9$ \\
Body mass $(\mathrm{kg})$ & $53.1 \pm 14.9$ & $52.6 \pm 15.1$ \\
BMI $\left(\mathrm{kg} / \mathrm{m}^{2}\right)$ & $25.2 \pm 3.3$ & $25.5 \pm 3.6$ \\
\#Values are the mean \pm SD. \\
Group 1: obese children with normal arch foot; \\
Group 2: obese children with flatfoot.
\end{tabular}

\section{Experimental Procedures}

Each participant's height and body mass were measured respectively to the nearest 0.1 $\mathrm{cm}$ and $0.1 \mathrm{~kg}$ barefoot by using a calibrated height and weight scale (Omron Corporation, Japan). All the anthropometric measurements were measured by a fixed experimenter.

A three-dimensional scanning system 
(Infoot, I-Ware Laboratory, Japan) was used to scan and measure the external foot morphology. The participant was under the weight-bearing condition of half body-weight (HWB) [15], and the external shape of each foot was laser scanned respectively and captured by eight cameras. In the HWB condition, the participant was in a balance standing posture with barefoot and eyes focused straight ahead for equal loads on both foot. Once the experimental device is moved, alignment is performed to the system before a new test. Both feet of each participant were tested only once respectively due to the high precision and high reliability of the device.

A footscan ${ }^{\circledR}$ plantar pressure plate system (RSscan International) was used to test the plantar pressure distribution during walking. This plate system included a $40 \mathrm{~cm} \times 100 \mathrm{~cm}$ platform with 4 sensors per square centimetres. A high sample frequency of $253 \mathrm{~Hz}$ was selected to record the data of dynamic plantar pressure. This plate was mounted on a smooth and level ground. Each participant was tested using a two-step gait initiation protocol [16]. After several practice runs under the experimenter's guidance, participants were then required to walk barefoot three times or more across the plate at self-preferred speed to complete the test procedure. Participants stood on one side of the walkway and about a meter away from the plate, then went across it to the other side of the walkway. Three trials of a participant were selected as valid by the following criteria: a whole gait cycle on the plate during naturally walking but not aiming at.

Footprints of each participant were taken by using a footprint plate (Bauerfeind AG, Germany). The underside of the membrane was inked and re-inked to keep a clear image before a new record. One piece of pedograph paper was placed beneath the membrane and mounted to the fixed position. The participant put one foot on the surface of the membrane and stood in a HWB condition, then the distinct footprint outline was taken by the experimenter with a special-purpose pen.

\section{Plantar Regions and External Foot Morphology}

Three-dimensional foot shape was measured by Delcam SoleEngineer 13.0 Software. Totally 38 foot dimensions were selected, including data of lengths, widths, heights, girths and hallux valgus angle. Totally 10 observed values which are necessary for shoe last design of obese children with flatfoot that are supposed to be valid in this study. Approach to measure the foot morphology is described in Table 2.

Table 2: Approach to measure the foot morphology

\begin{tabular}{lll}
\hline Foot Measure & Code & Description \\
\hline Foot Length & FL & Distance from the heel to the anterior point of the most protruding toe \\
Medial Ball Length & MBL & Distance from the heel to the $1^{\text {st }}$ MTP* MTP joint protrusion \\
Lateral Ball Length & LBL & Distance from the heel to the $5^{\text {st }}$ MTP joint protrusion \\
Forefoot Width & FW & Distance across the $1^{\text {st }}$ MTP joint to $5^{\text {st }}$ MTP joint protrusion on the $y$-axis \\
Ball of Foot Circumference & BFC & Circumference over the $1^{\text {st }}$ MTP joint and $5^{\text {st }}$ MTP joint protrusion \\
Instep Circumference & IC & Circumference over the tarsal protrusion and $5^{\text {st }}$ metatarsal tuberosity point \\
Navicular Circumference & NC & Circumference over the navicular point to the heel protrusion \\
Instep Height & IH & Distance from the prominent tarsal point to the ground plane \\
Navicular Height & NH & Distance from the navicular point to the ground plane \\
Hallux Valgus Angle & HVA & $\begin{array}{l}\text { Angle between the tangent of medial forefoot and hallux and medial tangent of } \\
\text { forefoot and heel }\end{array}$ \\
\hline
\end{tabular}


Ten plantar anatomical regions were defined by footscan 7 gait $2^{\text {nd }}$ generation (V7. 97) (Figure 1). Biomechanical parameters of peak pressure, contact area, pressure rate, pressuretime integral and force-time integral were extracted from the system for statistical analysis.

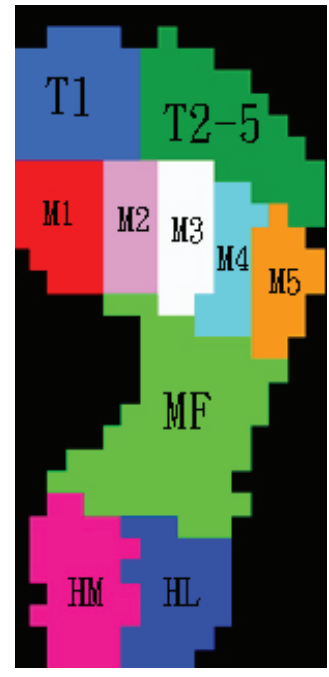

Figure 1. Ten anatomical regions of foot. T1: hallux, T2-5: $2^{\text {nd }}-5^{\text {th }}$ toes, M1: $1^{\text {st }}$ metatarsal, M2: $2^{\text {nd }}$ metatarsal, M3: $3^{\text {rd }}$ metatarsal, M4: $4^{\text {th }}$ metatarsal, M5: $5^{\text {th }}$ metatarsal, MF: midfoot,

HM: heel medial, HL: heel lateral.

\section{Reliability and Explore Analysis of the Variables}

All the foot dimensions were measured manually, so it is necessary to practice a testretest pilot study before the statistical analyses in this study. Totally 10 children (aged: 7-14, 5 boys and 5 girls) who were unrelated to the main subject cohorts were selected to perform the reliability of the procedures. Intraclass correlation coefficient (ICC) of the 10 anthropometric measurements, excluding hallux valgus angle, ranged from $\mathrm{R}=0.939$ to 0.943 . Therefore, the procedures were considered highly reliable and reproducible.
Explore analysis was conducted to screen the data preliminarily before testing. The outliners and extreme values which were out of the range between 25th and 75th percentiles were eliminated. All the absolute foot measurements were normalized to the respective foot length to eliminate the impact of foot length on other foot measurements.

\section{Statistical Analysis}

Hylton [17] has suggested that incorrect results from paired data can be avoided by only selecting one foot. In addition, no significant difference was found between left and right foot for obese children with flatfoot and obese children with normal arch foot respectively in the present study. The author hereby chose right foot (the dominant foot) to perform the statistical analyses. One-simple KolmogorovSmirnov test was used to perform all data for normality. The result shows all data comply with normal distribution. Independent t test was then used to perform the statistical analyses. $p$ values less than 0.05 were perceived as significant in all statistical description. SPSS software (version 17.0 for Windows; SPSS Corp., Chicago, IL) was conducted to perform the analysis procedures.

\section{RESULTS}

\section{External Foot Morphology}

Comparison by arch height with absolute and normalized foot measures, significant differences of foot morphology between the OFF group and the ONAF group are presented in Table 3. In absolute terms, the OFF group displayed significantly lower instep height and navicular height than the ONAF group $(p<0.01)$. When the foot measurements were normalized to the length of the respective foot, statistical analyses indicated that difference of navicular height disappeared, and significantly lower instep height and longer instep circumference were found in the OFF group ( $p<0.001)$.

Table 3: Values of absolute and normalized foot measures of ONAF group and OFF group

\begin{tabular}{lcccc}
\hline & \multicolumn{1}{c}{ ONAF } & OFF & $t$-value & $p$-value \\
\hline \multicolumn{2}{l}{ Absolute Measures $(\mathrm{mm})$} & & & \\
$\mathrm{FL}$ & $223.9 \pm 17.1$ & $220.8 \pm 16.3$ & 0.72 & 0.48 \\
$\mathrm{IH}$ & $60.1 \pm 6.2$ & $55.9 \pm 5.1$ & 2.85 & $<0.01$ \\
$\mathrm{NH}$ & $73.0 \pm 7.0$ & $68.3 \pm 6.1$ & 2.80 & $<0.01$
\end{tabular}


Foot Measures (\% of foot length)

\begin{tabular}{ccccc} 
MBL & $75.0 \pm 1.3$ & $75.2 \pm 1.1$ & -0.61 & 0.54 \\
LBL & $65.6 \pm 2.2$ & $64.7 \pm 1.9$ & 1.67 & 0.10 \\
FW & $39.5 \pm 1.1$ & $40.2 \pm 1.8$ & -1.95 & 0.06 \\
BFC & $99.8 \pm 3.1$ & $101.0 \pm 4.1$ & -1.31 & 0.20 \\
IC & $102.2 \pm 3.0$ & $105.7 \pm 4.0$ & -3.75 & $<0.001$ \\
NC & $133.9 \pm 13.3$ & $133.6 \pm 13.8$ & 0.08 & 0.94 \\
IH & $26.8 \pm 1.7$ & $25.4 \pm 1.8$ & 3.26 & $<0.01$ \\
NH & $32.8 \pm 4.2$ & $31.1 \pm 3.5$ & 1.77 & 0.08 \\
\hline
\end{tabular}

"Values: mean \pm SD.

Group 1: obese children with normal arch foot; Group 2: obese children with flatfoot.

\section{Dynamic Plantar Pressure Distribution}

Descriptive data of the plantar pressure is presented in Tables 4-5. Statistical analyses indicated that no significant difference for peak pressure was found beneath all plantar regions between the OFF group and the ONAF group, except the elevated peak pressure of the OFF group beneath the $2^{\text {nd }}-5^{\text {th }}$ toes region ( $p=$ 0.026). Significantly greater pressure rate and larger contact area of the OFF group were found beneath the midfoot region compared to the ONAF group $(p=0.002, p<0.001)$.

Table 4: Descriptive statistics ${ }^{\#}$ of peak pressure, contact area and pressure rate for ONAF group and OFF group

\begin{tabular}{|c|c|c|c|c|c|c|}
\hline \multirow[b]{2}{*}{ Regions } & \multicolumn{2}{|c|}{ Peak Pressure $\left(\mathrm{N} / \mathrm{cm}^{2}\right)$} & \multicolumn{2}{|c|}{ Contact Area $\left(\mathrm{cm}^{2}\right)$} & \multicolumn{2}{|c|}{ Pressure Rate $\left(\mathrm{N} / \mathrm{cm}^{2} . \mathrm{ms}\right)$} \\
\hline & ONAF & OFF & ONAF & OFF & ONAF & OFF \\
\hline $\mathrm{T} 1$ & $4.64 \pm 2.21$ & $5.61 \pm 2.04$ & $14.37 \pm 2.12$ & $14.67 \pm 2.31$ & $0.02 \pm 0.01$ & $0.02 \pm 0.01$ \\
\hline $\mathrm{T} 2-5$ & $1.08 \pm 0.54$ & $1.50 \pm 0.84^{*}$ & $17.85 \pm 3.87$ & $19.25 \pm 3.81$ & $0.01 \pm 0.01$ & $0.02 \pm 0$ \\
\hline M1 & $5.05 \pm 1.91$ & $5.11 \pm 1.84$ & $15.84 \pm 2.85$ & $15.94 \pm 2.38$ & $0.02 \pm 0.01$ & $0.02 \pm 0.01$ \\
\hline $\mathrm{M} 2$ & $10.87 \pm 3.94$ & $10.94 \pm 3.38$ & $9.31 \pm 1.64$ & $9.32 \pm 1.83$ & $0.03 \pm 0.02$ & $0.03 \pm 0.01$ \\
\hline M3 & $12.28 \pm 3.97$ & $12.49 \pm 3.94$ & $8.67 \pm 1.60$ & $8.60 \pm 1.31$ & $0.03 \pm 0.02$ & $0.03 \pm 0.01$ \\
\hline M4 & $10.46 \pm 3.54$ & $9.60 \pm 3.26$ & $8.27 \pm 1.58$ & $8.36 \pm 1.31$ & $0.03 \pm 0.01$ & $0.03 \pm 0.02$ \\
\hline M5 & $5.73 \pm 2.35$ & $4.71 \pm 2.08$ & $9.46 \pm 1.91$ & $9.48 \pm 1.22$ & $0.02 \pm 0.01$ & $0.02 \pm 0.01$ \\
\hline MF & $3.42 \pm 1.19$ & $3.96 \pm 1.05$ & $36.16 \pm 7.72$ & $43.80 \pm 7.23^{* *}$ & $0.02 \pm 0.01$ & $0.04 \pm 0.02^{* *}$ \\
\hline HM & $9.48 \pm 2.48$ & $9.15 \pm 1.79$ & $17.17 \pm 2.82$ & $16.83 \pm 2.91$ & $0.18 \pm 0.15$ & $0.22 \pm 0.19$ \\
\hline $\mathrm{HL}$ & $9.05 \pm 2.04$ & $8.58 \pm 1.60$ & $14.80 \pm 2.47$ & $14.28 \pm 2.42$ & $0.25 \pm 0.22$ & $0.34 \pm 0.31$ \\
\hline
\end{tabular}
"Descriptive statistics: mean \pm SD.

${ }^{* *}$ Significant difference $(P<0.01)$, ${ }^{*}$ Significant difference $(P<0.05)$.

Significantly greater pressure-time integral of the OFF group was found beneath the $2^{\text {nd }}$ $5^{\text {th }}$ toe region $(p=0.024)$. Increased force-time integral of the OFF group was found in the $2^{\text {nd }}-5^{\text {th }}$ toe $(p=0.014)$ and midfoot regions $(p=0.034)$. While significantly greater pressure-time integral and force-time integral were found for the ONAF group beneath the $5^{\text {th }}$ metatarsal region.

Table 5: Descriptive statistics ${ }^{\#}$ of pressure-time integral and force-time integral for ONAF group and OFF group

\begin{tabular}{|c|c|c|c|c|}
\hline \multirow[b]{2}{*}{ Regions } & \multicolumn{2}{|c|}{ Pressure-Time Integral $\left(\mathrm{N} / \mathrm{cm}^{2} . \mathrm{s}\right)$} & \multicolumn{2}{|c|}{ Force-Time Integral $(\mathrm{N} \cdot \mathrm{s})$} \\
\hline & ONAF & OFF & ONAF & OFF \\
\hline $\mathrm{T} 1$ & $1.37 \pm 0.80$ & $1.74 \pm 0.82$ & $20.20 \pm 11.64$ & $26.28 \pm 13.59$ \\
\hline T2-5 & $0.25 \pm 0.14$ & $0.37 \pm 0.25^{*}$ & $4.91 \pm \mathbf{3 . 2 8}$ & $7.73 \pm 5.11^{*}$ \\
\hline M1 & $1.70 \pm 0.76$ & $1.79 \pm 0.88$ & $28.02 \pm 12.82$ & $30.04 \pm 14.63$ \\
\hline
\end{tabular}




\begin{tabular}{|c|c|c|c|c|}
\hline M2 & $3.84 \pm 1.57$ & $3.78 \pm 1.44$ & $37.71 \pm 18.63$ & $36.82 \pm 16.29$ \\
\hline M3 & $4.44 \pm 1.58$ & $4.25 \pm 1.29$ & $41.20 \pm \mathbf{2 0 . 2 0}$ & $38.29 \pm 14.17$ \\
\hline M4 & $3.86 \pm 1.28$ & $3.41 \pm 1.01$ & $34.05 \pm 14.16$ & $29.76 \pm 10.86$ \\
\hline M5 & $1.95 \pm 0.90$ & $1.51 \pm \mathbf{0 . 6 0 ^ { * }}$ & $19.71 \pm 10.44$ & $15.10 \pm 6.97^{*}$ \\
\hline MF & $1.22 \pm 0.57$ & $1.38 \pm \mathbf{0 . 4 8}$ & $47.48 \pm 29.85$ & $64.0 \pm 28.99^{*}$ \\
\hline HM & $3.15 \pm 0.94$ & $2.77 \pm 0.97$ & $56.58 \pm 21.50$ & $49.88 \pm 25.01$ \\
\hline $\mathrm{HL}$ & $2.95 \pm 0.90$ & $2.51 \pm 0.96$ & $45.44 \pm 16.95$ & $38.25 \pm 19.69$ \\
\hline
\end{tabular}

\section{DISCUSSION}

This study, to our knowledge, is the first study to explain the effect of different foot type (flat or normal) on the foot morphology and dynamic plantar pressure distributions of obese aged 7-14 years. The results of the study indicated that different foot type can influence the foot morphology and foot loading patterns in the specific foot regions.

From the results of absolute foot measurements, ONAF group displayed greater instep height and navicular height. However, when the foot measurements were normalized to the foot length, the significant difference of navicular height disappeared. Furthermore, another significantly longer instep circumference of the OFF group showed up. It is speculated that lower instep height for OFF group might be attributable to the deformity of arch structure. Mickle et al. [18] measured the foot anthropometry and arch index of 19 preschool children with overweight/obesity, their findings confirmed that the flatter foot of children with overweight/obesity was caused by the arch structure change in the midfoot region. The result of the study also showed that OFF group displayed longer instep circumference. It is speculated that as a crucial foot anthropometry, the increase of longer instep circumference can result in the increase of midfoot width. A detailed knowledge involved in matching the foot to the construction of the shoe is of prime importance, it is perceived as a prerequisite for functional design of footwear [19]. It is known to all that the foot is very sensitive to the tiny changes in the shoe's structure. Obese children with flatfoot tolerate heavier loading and suffers more pain beneath their foot, so it is necessary to design specific shoe lasts for them. However, to our knowledge, only foot measurements in length and in width were considered into the shoe last design in the traditional way. In this study, it is suggested that foot measurements in girth and in height should be incorporated into shoe last design to further improve the shoe last for obese children with flatfoot. Small variations in foot morphology must be considered into the shoe last design to match the foot shape in order to protect the foot well.

Several studies have indicated the effect of foot type on development of lower extremity overuse injuries [10, 20, 21]. However, no consensus has been reached in the previous studies with respect to the effect of foot type on the risk of foot and ankle injuries. The greater peak pressure was found for the OFF group beneath the 2 nd-5th toe region compared to their counterparts, while Chuckpaiwong et al. [12] and Queen et al. [11] indicated that no significant shift in lesser toes loading between the participants with different foot type. Due to the different BMI reference norm, it is speculated that testing conditions such as racial background and environmental factors, rather than BMI alone, can probably explain different foot loading pattern among different population.

The significantly greater pressure-time integral and force-time integral were found for the OFF group beneath the 2nd-5th toe region, while a decrease was found beneath the 5th metatarsal region. These results were in line with the previous studies which indicated that individuals with a flat foot could be at a lower risk for lateral column metatarsal stress fractures [12]. The results of this study indicated a greater force-time integral beneath the midfoot region of the OFF group, which implied a potential higher 
risk for midfoot injuries than the ONAF group. A previous study has indicated that increased forcetime integral can imply the potential damage to the foot structure [25]. Therefore, collapse of arch structure can deteriorate the plantar load condition of obese children with flatfoot during walking. Pressure rate is an relative parameter of plantar pressure used to describe the rate of pressure changes per millisecond and assess cushioning function of the foot [26]. Significantly increased pressure rate found for the OFF group beneath the midfoot region further confirms that midfoot has a high risk of arch collapse and stress fractures.

\section{CONCLUSIONS}

This study investigated the effects of foot type on foot morphology and dynamic plantar pressure distributions of obese children. From the results, we can conclude that small variations in foot morphology must be considered into the orthopaedic shoe last design to assist the treatment of flatfoot. Moreover, obese children with flatfoot more likely suffer from pain in the midfoot region during walking, because they not only have to tolerate excessive body mass, but also be at a high risk of foot pathology. Therefore, obese children with flatfoot could be at an increased risk for midfoot injuries such as stress fractures which can adversely affect the foot development of children.

\section{Acknowledgments}

The present study obtained financial support from National Natural Science Foundation of China, grant number: 11502154. The authors would like to acknowledge all the experimenters for subject recruitment and data collection, and to acknowledge all the participants who made this study possible. No writing assistance we had in this paper.

\section{REFERENCES}

1. Chen, K.C., Yeh, C.J., Tung, L.C., Yang, J.F., Yang, S.F., Wang, C.H., Relevant factors influencing flatfoot in preschool-aged children, Eur $J$ Pediatr, 2011, 170, 7, 931-6, https://doi. org/10.1007/s00431-010-1380-7.
2. El, O., Akcali, O., Kosay, C., Kaner, B., Arslan, Y., Sagol, E. et al., Flexible flatfoot and related factors in primary school children: a report of a screening study, Rheumatol Int, 2006, 26, 11, 1050-3, https://doi.org/10.1007/s00296006-0128-1.

3. Evans, A.M., The paediatric flat foot and general anthropometry in 140 Australian school children aged 7 - 10 years, J Foot Ankle Res, 2011, 4, 1, 12, https://doi. org/10.1186/1757-1146-4-12.

4. Sadeghi-Demneh, E., Jafarian, F., Melvin, J.M., Azadinia, F., Shamsi, F., Jafarpishe, M., Flatfoot in school-age children: prevalence and associated factors, Foot Ankle Spec, 2015, 8, 3, 186-93, https://doi. org/10.1177/1938640015578520.

5. Villarroya, M.A., Esquivel, J.M., Tomas, C., Moreno, L.A., Buenafe, A., Bueno, G., Assessment of the medial longitudinal arch in children and adolescents with obesity: footprints and radiographic study, Eur J Pediatr, 2009, 168, 5, 559-67, https://doi. org/10.1007/s00431-008-0789-8.

6. Pfeiffer, M., Kotz, R., Ledl, T., Hauser, G., Sluga, M., Prevalence of flat foot in preschool-aged children, Pediatrics, 2006, 118, 634-639, https://doi.org/10.1186/1757-1146-2-25.

7. Chang, J.H., Wang, S.H., Kuo, C.L., Shen, H.C., Hong, Y.W., Lin, L.C., Prevalence of flexible flatfoot in Taiwanese school-aged children in relation to obesity, gender, and age, Eur J Pediatr, 2010, 169, 4, 447-52, https://doi. org/10.1007/s00431-009-1050-9.

8. Mauch, M., Grau, S., Krauss, I., Maiwald, C., Horstmann, T., Foot morphology of normal, underweight and overweight children, Int J Obes (Lond), 2008, 32, 7, 1068-75, https:// doi.org/10.1038/ijo.2008.52.

9. Chen, J.P., Chung, M.J., Wang, M.J., Flat foot prevalence and foot dimensions of 5- and 13-year-old children in Taiwan, Foot Ankle Int, 2009, 30, 326-332, https://doi.org/10.3113/ FAI.2009.0326. 
10.Kaufman, K.R., Brodine, S.K., Shaffer, R.A., Johnson, C.W., Cullison, T.R., The effect of foot structure and range of motion on musculoskeletal overuse injuries, Am J Sports Med, 1999, 27, 5, 585-93, https://doi.org/10. 1177/03635465990270050701.

11.Queen, R.M., Mall, N.A., Nunley, J.A., Chuckpaiwong, B., Differences in plantar loading between flat and normal feet during different athletic tasks, Gait Posture, 2009, 29, 4, 582-6, https://doi.org/10.1016/j. gaitpost.2008.12.010.

12.Chuckpaiwong, B., Nunley, J.A., Mall, N.A., Queen, R.M., The effect of foot type on in-shoe plantar pressure during walking and running, Gait Posture, 2008, 28, 3, 405-11, https://doi. org/10.1016/j.gaitpost.2008.01.012.

13.Forriol, F., Pascual, J., Footprint analysis between three and seventeen years of age, Foot Ankle Int, 1990, 11, 101-104, https://doi. org/10.1177/107110079001100208.

14.Force GoCOT, Body mass index reference norm for screening overweight and obesity in Chinese children and adolescents, Chin J Epidemiol, 2004, 25, 97-102.

15.Xiong, S., Goonetilleke, R.S., Zhao, J., Li, W., Witana, C.P., Foot deformations under different load-bearing conditions and their relationships to stature and body weight, Anthropol Sci, 2009, 117, 2, 77-88, https:// doi.org/10.1537/ase.070915.

16. Hallemans, A., De Clercq, D., Van Dongen, S., Aerts, P., Changes in foot-function parameters during the first 5 months after the onset of independent walking: a longitudinal follow-up study, Gait Posture, 2006, 23, 2, 142-8, https:// doi.org/10.1016/j.gaitpost.2005.01.003.

17.Menz, H.B., Two feet, or one person? Problems associated with statistical analysis of paired data in foot and ankle medicine, The Foot, 2004, 14, 1, 2-5, https://doi.org/10.1016/ S0958-2592(03)00047-6.

18.Mickle, K.J., Steele, J.R., Munro, B.J., The Feet of Overweight and Obese Young Children: Are They Flat or Fat?, Obesity, 2006, 14, 1945-
1953, https://doi.org/10.1038/oby.2006.227.

19.Hawes, M.R., Sovak, D., Quantitative morphology of the human foot in a North American population, Ergonomics, 1994, 37, 7, 1213-26, https://doi. org/10.1080/00140139408964899.

20.Kanatli, U., Yetkin, H., Yalcin, N., The relationship between accessory navicular and medial longitudinal arch: evaluation with plantar pressure distribution measurement system, Foot Ankle Int, 2003, 24, 6, 486-489, https:// doi.org/10.1177/107110070302400606.

21.Ledoux, W.R., Hillstrom, H.J., The distributed plantar vertical force of neutrally aligned and pes planus feet, Gait Posture, 2002, 15, 1, 1-9.

22.Kim, H.W., Weinstein, S.L., Flatfoot in children: Differential diagnosis and management, Current Orthopaedics, 2000, 14, 6, 441-447, https://doi.org/10.1054/cuor.2000.0156.

23.Kanatli, U., Yetkin, H., Cila, E., Footprint and radiographic analysis of the feet, $J$ Pediatr Orthop, 2001, 21, 2, 225-8.

24.Harris, E.J., Vanore, J.V., Thomas, J.L., Kravitz, S.R., Mendelson, S.A., Mendicino, R.W. et al., Diagnosis and treatment of pediatric flatfoot, J Foot Ankle Surg, 2004, 43, 6, 341-73, https:// doi.org/10.1053/j.jfas.2004.09.013.

25.Filippin, N., Barbasa, V., Sacco, I., Lobo da Costa, P., Effect of obesity on plantar pressure distribution in children, Braz J Phys Ther, 2007, 11, 495-501.

26.Yan, S.H., Zhang, K., Tan, G.Q., Yang, J., Liu, Z.C., Effects of obesity on dynamic plantar pressure distribution in Chinese prepubescent children during walking, Gait Posture, 2013, 37, 1, 37-42, https://doi.org/10.1016/j. gaitpost.2012.05.018.

(C) 2017 by the author(s). Published by INCDTP-ICPI, Bucharest, RO. This is an open access article distributed under the terms and conditions of the Creative Commons Attribution license (http://creativecommons.org/licenses/ by/4.0/). 